Meta

Journal des traducteurs

Translators' Journal

\title{
The Impact of Translation on Target Language Discourse: Text
} vs. System

\section{Albrecht Neubert}

Volume 35, numéro 1, mars 1990

Actes du colloque international « La traduction proligère "

URI : https://id.erudit.org/iderudit/003725ar

DOI : https://doi.org/10.7202/003725ar

Aller au sommaire du numéro

Éditeur(s)

Les Presses de l'Université de Montréal

ISSN

0026-0452 (imprimé)

1492-1421 (numérique)

Découvrir la revue

Citer cet article

Neubert, A. (1990). The Impact of Translation on Target Language Discourse: Text vs. System. Meta, 35(1), 96-101. https://doi.org/10.7202/003725ar d'utilisation que vous pouvez consulter en ligne. 


\title{
THE IMPACT OF TRANSLATION ON TARGET LANGUAGE DISCOURSE TEXT VS. SYSTEM
}

\author{
ALBRECHT NEUBERT \\ Karl-Marx Universität, Leipzig, GDR
}

Understandably, the main concern of translation studies as well as the chief aim of translation practice has centred on the successful process of mediating texts from the source to the target language. The criteria to be taken into account all have to do with how the translation has managed to achieve a reasonably high degree of communicative or functional equivalence to the original. In other words, the debate or rather the cline of opinions ranging from an outright denial of so-called equivalence to a realistic acceptance of a rich scope of pragmatic adaptations functioning as TL substitutes for SL stimuli usually start out and again end up with pretty static views of the two codes themselves (SL and TL) that form the all-inclusive sign background of what goes on in translation.

By static I mean the state of the SL system that has lent its material, i.e., its forms and meanings, to the source text as well as the state of the TL system, from which translators can make their choices. It is true that the SL texts as well as the TL texts represent unique selections made on the basis and by means of the two respective verbal systems. In particular, it is taken for granted that the original may exhibit idiosyncratic features, which though rooted in the SL system employ verbal means in a new or unexpected way. Words and sentences expressing novel things and events, actions and situations in a new light can do so because their lexical and syntactic make-up deviates in subtle, often imperceptible ways from the socially engrained norms of the SL system. Due to what has been termed dynamic synchrony this state of affairs is nothing unusual. It is part and parcel of textuality banking on the inexhaustible resources of the language system rather than a serious violation of its underlying set of rules.

Similarly, but perhaps not to the same degree, translators have the option of making unlimited use of all potential features of the TL system. The context of translation allows for new uses the linguistic means of the TL may be put to which, provided that the terms of the dynamic synchrony are adhered to. Just as the producer of the SL text is creative, translators are entitled to their own share of creativity.

This way of looking at translation, however correct by itself, leaves out a number of side issues, i.e., of lesser importance to the individual translation as well as to the job of the translator but, I think, of quite some significance to the topic of this colloquium. If I have, nevertheless, opened my paper by highlighting the dynamics of the two language systems involved in the individual translation process, my purpose for this will be quite evident when I point out the hidden ties between traduction dynamique et traduction proligère. In fact, what I have so far described on the level of the (individual) translational process has but to be transposed onto the level of large-scale translational activity between the SL and TL speech communities. What was, in the above context, a creative one-off act performed by one translator is now expanded to the much wider and more generalized context. It turns into a permanent influence exerted by many translators and translations on the system of the TL. 
The history of translation abounds in cases where TL texts have left deep imprints on the linguistic habits of TL communities. The transfer of Christian doctrine or of classical learning originally encoded in Latin and Greek texts has transformed the TL systems of English and of other modern European languages tremendously. Only note the impact of Latin syntax on early English, in particular on what has become elaborate clausal subsystems implemented, to a very large extent, by loan-translated infinite verb constructions. More evident, on the surface, are the countless inroads into a predominantly Germanic lexicon effected by French and Latin/Greek words and word meanings. In more recent times the enormous translational activity concerned with the propagation and dissemination of the procedures and results of the scientific and technical revolution has left indelible marks on many languages. And there is no doubt that the SL has been mostly English. Less sweeping but just as profound traces have been left in the course of the subtle interaction between national literatures which was promoted, first and foremost, by translation. In actual fact, the history of languages such as English or German cannot be fully grasped and explained without due recourse to the impact of translation, a case in point being the role Luther's Bible translation played for the rise of modern High German.

In order for us to appreciate the pervasive seminal influence of extensive material in translation, the contours of the picture sketched so far have to be re-drawn with a more revealing mise en relief. It is not enough to stress that the impact of translation is the impact of texts, very rarely one text, more commonly series or networks of intertextually related texts. Indeed, texts are the true mediators between the SL and the TL systems. Systems per se cannot be translated at all, unless one conceives the text as a communicative system of its own. But what actually exerts the influence are recurrent series of such texts or textual systems within the communicative world or sphere of the TL community. One can indeed speak of a translational discourse integrated into the "normal" (nontranslated) discursive practice of native TL users.

As is well known, textual conventions are by no means uniform. Although they are rooted in a particular language system, they are at the same time distinct from the totality of systemic rules. They are coextensive with particular or favourite predilections for sets of signs and sign combinations as against the use of generally applicable all-systemic features. These specific choices cluster around certain classes or groups of texts. And it is precisely within the frame of reference of a particular text class that a translation or rather a tradition of translating becomes seminal. Translations act out their influence in groups. They affect TL text classes. And this contextual environment makes it possible that new textual conventions are tolerated by the TL audience, which is not really the TL community as a whole but a selected segment of it, viz. those TL readers who are primarily interested in the information supplied by the particular group of texts.

It is an open question entirely to be decided by pragmatic conditions, governing the communicative strategies and tactics in the TL community, which group of (translated) TL texts may be successful in channelling its novel features beyond its sphere of influence into the wider realms of the TL system. It cannot be predicted in the first place whether those novel features occurring in groups of translations catch on, i.e., enter the overall TL system. This is perhaps not even a relevant point, after all. As soon as certain translational innovations become fully entrenched in a specific class of text, say in the field of advertising, when "normal" $\mathrm{TL}$ texts that are not translations frequently and consistently show typical features borrowed from genuine translations, the carry-over into the TL can be said to have occurred. One can say, somewhat irreverently, that the SL features that have made their way into groups of TL texts via translation are up for grabs by original TL writers. They may be used just as regular TL elements. In fact, they may even be highly frequent markers of TL text classes. Their SL origin may still be felt or 
not. What counts as much more important is their text-type distinguishing feature. The world of TL texts has naturalized them as a fully integrated part of their norms.

Texts act as filters between two linguistic systems. It is also in a text-type that a synchronous system actually becomes alive. Certain features of the system are restricted to or at least concentrated upon classes of texts. And it is only via texts or sorts of texts that languages become enriched. Translations provide a unique kind of adaptive tool that safeguards the transmission of new information within the framework of familiar TL items and structures. The accommodation of the old TL text-type under pressure from the textual contours derived from the SL original is achieved with relatively little effort on the side of the TL user of the translation. Of course, the translator's task covered up neatly in the smooth flow of the TL signs was much harder to achieve and it certainly took all the insights and lessons of previous experience to model a translation along the lines of a particular text-typological norm.

Included in this job is the observance of textual conventions which correspond to the interested TL users' patterns of expectation. How often are novice translators surprised, perhaps even shocked at the reaction of subject specialists who re-translate certain passages of a nicely TL-worded text because they insist on terms and phrases that the TL-conscious translator had expressly eliminated. But the experts' notion of what satisfies a particular technical text class is a far cry from the translators' concept of a good TL instance. In other words, the impact of translation, specialist translations at that, is no longer felt as un-TL. The opposite is the case. That the SL-patterns look through is regarded as a perhaps novel, but certainly an in-feature of many modern normal TL texts, especially of a scientific or a technical nature, e.g. medicine, physics, electronics, etc. But also in business and, in particular, in advertising such a carry-over can be easily observed. Another case in point is journalism. Note, for instance, the way news and newsprint are laid out in a large number of (West) German newspapers and magazines.

It should, however, be noted that this trend of incorporating SL features into the translation and, as an inevitable result, into TL discourse may have its negative aspects. The borderline between enriching and corrupting TL habits is tenuous. Remember the infamous inkhorn controversy during the age of New Learning. This debate has been going on, in fact it has been raging ever since. I will only quote a very recent criticism vented against the literal translation of Russian texts into American English, more specifically, Soviet military publications into U.S. defence publications. A most telling protest was published by a USAF Lieutenant-Colonel in the British journal Defence Analysis. Under the apt title "The 'Sovietization' of the English Language," it singled out a number of typical Russicisms which inadvertently have already entered American military jargon. But instead of enlightening U.S. readers they have given rise to quite erroneous or at least ambiguous conceptions of Soviet reality.

Examples are nonce-words like radioelectronics for what should be just electronics (a literal rendering of Russian radioelektronika, rocket for missile (Russian raketa), ballistic rockets of strategic designation for strategic missile forces (Russian balisticheskije rakety strateticheskovo naznachenija), general-lieutenant and lieutenant-major for lieutenant-general and major-general, camouflage, concealment, and deception for camouflage (Russian maskirovka), disinformation for deception or fabricated information (Russian maskirovka), and radioelectronic combat for electronic warfare (Russian radioelektronnaja bor'ba).

The author remarks The Soviet Union is examined ad nauseam by many Soviet specialists totally at the mercy of translation. Even worse, they are sometimes oblivious to improper English usage, judging by the unquestioning acceptance of translation ambiguity or "non-words" and the hasty perpetuation of derivative misconceptions. And he 
concludes: Not uncommonly a single instance of ambiguity intruded into the English language without resistance from either curious or knowledgeable readers is multiplied several times and ultimately enshrined in a doctrine of nonerrancy (Makinen 1985 : 37).

Although there are many detailed studies on the influence of translation on the TL, and although the main thrust of this research clearly corroborates our point that domain and text class exert a determining effect, it is surprising that language historians have so far devoted little attention to the mechanism of systematic change through translation. Historical linguistics has recently incorporated quite novel research patterns with the notion of variable functioning as a key concept. Instead of inventing or at least looking for new sounds, structures or meanings the language community and its partitions rather have to cope with an embarras de richesse. When something new gets accepted it is often the result of but an accommodative innovation (Coates 1987 : 184). Certain variables, having existed side by side with other more prestigious ones, become gradually more dominant and are preferred to the originally accepted ones. Now these variables may not be only regional, social, functional (stylistic, register, etc.) variants of the same language but result from translations. Translations are favourite suppliers of new variables. As pointed out earlier, translational variables are usually centred around certain text-types. A class of text, then, should be viewed as another quite important variable that offers choices for the TL user. From the point of view of the translator it is the vehicle transporting SL meaning into the TL. The context of the TL text and, what is more, the support of the (new) text-type conventions guarantee the acceptability of the borrowed items and arrangements.

Modern languages, there is no doubt, exhibit variable resources to accommodate SL influences. These spread across the whole of linguistic levels from the sound level to that of meaning. The repertoire of language borrowing classified and exemplified in many studies on languages in contact can be profitably used not only in case studies describing the impact of particular translations, but should also be exploited in more ambitious projects elucidating the overall effect of large-scale translational activities on the communicative conventions of TL cultures over a longer period of time. Translations of great numbers of texts and, as pointed out, translational reverberations reflected in whole classes of TL texts have become the rule in our age. In substance, if not in quantity, this phenomenon is as old as different language communities have been in contact. But research covering just these large-scale interactions and correspondences between translation and the state and fate of languages into which was translated is remarkably sparse, if not inexistent. But it is actually here where la traduction proligère finds its dominant testing ground. Here we come across the most powerful effects. Here we gather evidence of text-translational transfer in TL accommodations to

\section{SL pronunciation \\ SL morphology \\ SL word-formation \\ SL syntax \\ SL semantics \\ SL phraseology}

Just as studies in borrowing (independent from translation, if such a thing exists), two basic processes can be distinguished: either the TL use of (more or less unchanged) SL signs or the use of TL signs with (more or less genuine) SL meanings. Both these kinds of SL $\rightarrow$ TL impacts may be broken down into subdivisions, for instance, as in borrowing, various types of semantic shifts effected by differing accommodatory procedures among the TL items. For instance, loan formations or loan creations represent TL 
signs and sign combinations that realize the SL model through formal means. Loan meanings, on the other hand, leave the substance of TL material unchanged but add notional content that deviates significantly from established TL usage.

As against conservative standpoints favouring an ideal of language purity, more recent views have tended more and more towards the pragmatic view that translations fertilize the communicative practices of TL users. Under the impact of SL discourse the TL user accesses untapped resources that had lain dormant. A case in point is the way TLs develop their potential for terminologies as a result of translational cross-fertilization. Languages with more sophisticated special terminologies, in the course of getting translated via large quantities of technical texts, inculcate their terminological experience upon receptor cultures and their nascent terminologies. A special number of META (1987) presented an admirable account of the multifaceted processes that can be discerned as terminological fertilization of the Romance languages with English being the main SL.

It should, however, be noted that the unidirectional process from SL texts to TL texts has yet another, international dimension. Certain text-types, those that are marked by particularly high translational incidence, are almost simultaneously put into quite a number of languages. Thus what is, on the one hand, a TL way to come to terms with one SL, mainly English, on the other hand, turns out to be a major step towards an internationalization of terminologies. In the context of the theme of this colloquium this means that the impact of translation, in our epoch, is to a growing extent multidirectional. It is true that individual TLs each cope with this verbal influx in their own specific ways. But the actual outcome, however varied it may be from TL to TL, is also invariably marked by many internationalisms. The situation resembles somewhat the internationalisms of Greek and Latin origin in the age of New Learning and the Renaissance. But at present it is not so much the translation of a limited number of canonical works as in those earlier times. What characterizes the contemporary situation is rather a mass effect that springs from the ubiquitous translation of thousands of thousands of relatively small texts of similar character each containing or supposed to contain little pieces of new and decisive information. Furthermore, the nationality of the sender is more and more hidden behind the message to be translated. One proof of this tendency can be deduced from the fact that many researchers write up their papers and reports in English although it is not their mother tongue. Nevertheless this should not divert our attention from the other equally important fact that the genuine propagation of information acquired worldwide presupposes translation into national languages. Education as well as the practical implementation of research and development cannot be adequately achieved in any country without an up-to-date body of systematized knowledge and know-how encoded in the texts of a national language. Otherwise the intellectual and practical resources of the majority of people could not be mobilized.

Here again we are faced with the ever-growing importance of translation. There will be, for instance, no transfer of technology from more advanced to less advanced countries without translation (Harris 1983). But equally true is the lasting imprint of all those life-saving translations on the TLs. In conclusion, one can say that the impact of translation on all levels of the TL is the price one's mother tongue has to pay for a permanently updated ticket to the treasure-house of world knowledge. But it would be equally correct to say, perhaps even more to the point, that the subtle effects of translation achieve much more than an accommodatory rapprochement of the TL towards the SL. In actual fact, translations are midwives that make sure that the TLs, far from being passive receptacles, are really reborn time and again. 


\section{REFERENCES}

ALGARDY, F., P. LERAT, and J.-P. VAN DETH (1987) : "La fertilisation terminologique dans les langues romanes", Actes du colloque de Paris, october 1986, META, 32:3, pp. 217-370.

COATES, R. (1987) : "Historical Linguistics", in John Lyons et al. (eds), New Horizons in Linguistics 2, London and Harmondsworth, Penguin, pp. 179-199.

HARRIS, B. (ed.)(1983): "La traduction dans le monde", META, 28:1, pp. 1-112.

MARKINEN, R. S. (1985) : "The 'Sovietization' of the English Language”, Defense Analysis, 1:1, pp. 37-49. 